\title{
Spouse caregivers perception of the end stages of life and death of the patient at hospital : an exploratory qualitative study during the mourning period
}

Benoit MAILLARD ${ }^{1}$, Marion DEREZ-PREL ${ }^{1}$, Nathalie DENIS-DELPIERRE ${ }^{1}$, Adrien EVIN ${ }^{1}$, Julien NIZARD ${ }^{1}$

Departement of Pain, Supportive and Palliative care, UIC 22, University Hospital and Faculty of Medecine, Nantes, France

\section{BACKGROUND}

Cancer patients have multiple needs, including management of symptoms, drug administration, emotional support and assistance with personal care.

Family caregivers experience their own emotional response to the announcement of the patient's prognosis, and may also require assistance and emotional support.

An updated systematic review of the literature concerning interventions designed to help the caregivers (1) of patients managed by home cancer and palliative care services demonstrates a rapid increase in the number of interventions over recent years. However, the range of available models remains limited in relation to the caregivers' needs and preferences.

In order to provide optimal support to family caregivers of cancer patients in the palliative care setting, clinicians must understand their perceptions of the complexity of the problems related to the patient's illness.

In this study, we therefore examined the perceptions of spouse caregivers at the end of life and until the patient's death in hospital.

\section{METHODS}

We used a qualitative methodology to investigate spouse caregivers' perceptions.

We adopted a constructivist grounded theory approach comprising individual semi-structured interviews.

We retrospectively interviewed family caregivers 3 months after the cancer patient's death.

This qualitative, cross-sectional study was conducted in a French university hospital palliative care unit between December 2015 and May 2016.

Face-to-face interviews were conducted in a place chosen by the participant. All interviews were transcribed and coded according to qualitative methods (grounded theory) using $N$ Vivo 10 qualitative analysis software. Coding and themes were examined and discussed by the research team members.

The study was approved by the medical research Ethics Committee.

\section{RESULTS}

Interviews were conducted with 15 spouses and were terminated when we considered that no new theme had emerged after several interviews

\begin{tabular}{|c|c|c|c|c|c|}
\hline & Participant characteristics : \\
\hline Number & $\begin{array}{c}\text { Participant's } \\
\text { age }\end{array}$ & $\begin{array}{c}\text { Participant's } \\
\text { gender }\end{array}$ & $\begin{array}{c}\text { Patient's } \\
\text { age }\end{array}$ & $\begin{array}{c}\text { Patient's } \\
\text { cancer type }\end{array}$ & $\begin{array}{c}\text { Years of } \\
\text { caregiving }\end{array}$ \\
\hline 1 & 58 & $\mathrm{~F}$ & 59 & Colorectal & $3-5$ years \\
\hline 2 & 57 & $\mathrm{M}$ & 59 & Breast & $6+$ years \\
\hline 3 & 48 & $\mathrm{~F}$ & 51 & Glioblastoma & $1-2$ years \\
\hline 4 & 55 & $\mathrm{~F}$ & 58 & Lung & $3-5$ years \\
\hline 5 & 62 & $\mathrm{~F}$ & 67 & Prostate & $3-5$ years \\
\hline 6 & 76 & $\mathrm{~F}$ & 79 & Other & $6+$ years \\
\hline 7 & 67 & $\mathrm{~F}$ & 67 & Pancreas & $1-2$ years \\
\hline 8 & 65 & $\mathrm{M}$ & 67 & Breast & $3-5$ years \\
\hline 9 & 73 & $\mathrm{M}$ & 71 & Colorectal & $3-5$ years \\
\hline 10 & 62 & $\mathrm{~F}$ & 67 & Glioblastoma & $1-2$ years \\
\hline 11 & 77 & $\mathrm{~F}$ & 78 & Other & $6+$ years \\
\hline 12 & 64 & $\mathrm{M}$ & 64 & Breast & $6+$ years \\
\hline 13 & 57 & $\mathrm{~F}$ & 59 & Colorectal & $3-5$ years \\
\hline 14 & 62 & $\mathrm{M}$ & 62 & Pancreas & $1-2$ years \\
\hline 15 & 58 & $\mathrm{~F}$ & 62 & Lung & $6+$ years \\
\hline
\end{tabular}

$>$ Four themes were identified :

- Impact of the disease on the patient's body:

"He no longer recognised his own body ... It was as if he had abandoned his body."

- Temporal discontinuity in the care pathway:

"We felt completely alone in relation to the world of medicine and examinations; we knew that something serious was happening, but we didn't really know what it was.

- Need for hope:

"You know, when you go to hospital, you hope you are going to be cured, even when we are told that there is nothing more that can be done."

- Integration and symbolization of losses:

"Deep down, I knew that I would be by his side until he died."

Certain themes that highlight the distress experienced by family caregivers reveal key elements of the care pathway that can have a negative impact on the caregivers' perception.

\section{CONCLUSION and PRACTICE IMPLICATIONS}

Spending time together is very important at the end of life. Although caregivers described this period as being difficult, they also described it as an intense but valuable period (2).Spouse caregivers set up processes of integration of loss and their own defence mechanisms to try to cope with this inevitable reality of end of life and death.

The principle of family-centered care, comprising family caregiver satisfaction in relation to palliative care, is proposed as a key indicator of quality of care. Particular attention should be paid to developing guidelines designed to improve the care pathway with special focus on assessment of the caregivers' natural resources and intervention designed to provide practical and psychological support to the caregivers of patients at the end of life.

It appears essential to devote more attention to caregivers during the patient's care pathway in order to limit their distress at the end of life, and during the first months of bereavement.

(1) Harding R1, List S, Epiphaniou E, Jones H. How can informal caregivers in cancer and palliative care be supported? An updated systematic literature review of interventions and their effectiveness. Palliat Med. 2012 Jan;26(1):7-22.

(2) Henriksson, A., Carlander I, Arestedt K. Feelings of rewards among family caregivers during ongoing palliative care. Palliat Support Care 2015; 13(6): 1509-1517. 